\title{
Influence of INM on Nutrient Uptake, Bio-chemical Properties of Soil and Yield Attributes of Paddy (Oryza sativa L.) under Hill Zone of Karnataka
}

\author{
Shreeshail $^{1}$, M. Hanumanthappa ${ }^{1 *}$ and M. Ganapathi ${ }^{2}$ \\ ${ }^{1}$ Department of Agronomy, ${ }^{2}$ Department of Crop Physiology, College of Horticulture, \\ Mudigere, University of Agricultural and Horticultural Sciences, \\ Shivamogga, Karanataka, India \\ *Corresponding author
}

\section{A B S T R A C T}

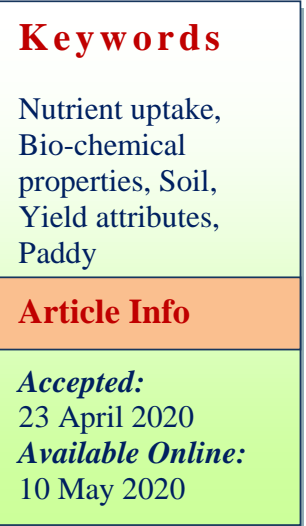

A field experiment was conducted at Zonal Agricultural and Horticultural Research Station, Mudigere, Chikkamagaluru district, Karnataka to investigate the integrated nutrient management in paddy under hilly zone of Karnataka during kharif season of 2018. The experiment was laid out in Randomized Complete Block Design consisting of ten treatments and replicated thrice. The result revealed that application of $100 \% \mathrm{RDF}+$ Glyricidia (50\%) + Eupatorium $(50 \%)+$ PGPR (T9) recorded significantly higher total nutrient uptake of NPK (110.81, 48.47 and $61.55 \mathrm{~kg}$ ha", respectively), yield attributing characters like number of productive tillers per hill $(18.41)$, panicle length $(22.29 \mathrm{~cm})$, panicle weight $\left(4.13 \mathrm{~g}_{\text {panicle }}{ }^{-1}\right)$ and number of filled grains per panicle (128) as compared to recommended dose of fertilizers alone. Significantly higher 1000 grain weight $(25.36 \mathrm{~g})$, grain yield $\left(5843 \mathrm{~kg} \mathrm{ha}^{-1}\right)$ and straw yield $\left(7477 \mathrm{~kg} \mathrm{ha}^{-1}\right)$ was recorded with application of $100 \%$ RDF + Glyricidia (50\%) + Eupatorium (50\%) + PGPR (T9) over other treatments. Combined application of 100 per cent recommended dose of fertilizers + glyricidia (50\%) + eupatorium $(50 \%)+$ PGPR treatment found significantly higher bacteria, fungi and actinomycetes population $\left(31.78 \mathrm{cfu} \times 10^{5} \mathrm{~g}^{-1}\right.$ of soil, $40.75 \mathrm{cfu} \times 10^{3} \mathrm{~g}^{-1}$ and $15.11 \mathrm{cfu}$ $\times 10^{4} \mathrm{~g}^{-1}$ of soil, respectively) and it was followed by 100 per cent recommended dose of fertilizers + glyricidia $(50 \%)+$ eupatorium $(50 \%)\left(29.50 \mathrm{cfu} \times 10^{3} \mathrm{~g}^{-1}, 39.82 \mathrm{cfu} \times 10^{3} \mathrm{~g}^{-1}\right.$ and $14.70 \mathrm{cfu} \times 10^{4} \mathrm{~g}^{-1}$ of soil, respectively).

\section{Introduction}

Rice (Oryza sativa L.) is an important and extensively cultivated food crop which feeds more than half of the world's population. It is second most widely consumed cereal in the world next to wheat. It is the staple food for two thirds of the world's population. In Asia alone, more than 2 billion people obtain 60 to
70 per cent of their energy intake from rice and its derivatives. India has the largest area among rice growing countries and it stands second in production next to China (Udhyakumar and Ramasamy, 2016). It produces 104.31 million tons of rice in an area of 44.38 million hectares (Agriculture Statistical year book, India 2017). The country has to produce about 130 million tons 
of rice by 2025 to meet the food requirement of the growing population (Hugar et al., 2009).

Imbalanced nutrient management under intensive cropping system and decreased soil organic matter are the key factors responsible for decline in soil quality parameters (Kang et al., 2005) such as deterioration of the physical, chemical and biological health of soils, and declined factor productivity, due to much higher annual removal of nutrients by crops and cropping systems than the amount added through fertilizers and resulted negative nutrient balance. Inorganic fertilizer is not a complete substitute for organic matter and vice-versa and their role is complementary to each other.

The increasing cost of chemical input, pollution, soil health and sustainability of the production system had generated interest in the integrated nutrient management. The integrated nutrient supply system is the most logical concept for managing long-term soil fertility and productivity (Ramesh et al., 2009). Use of chemical fertilizers and organic manures has been found promising in arresting the decline trend in soil-health and productivity through the correction of marginal deficiencies of some secondary and micro-nutrients, micro-flora and fauna and their beneficial influence on physical and biological properties of soil. Integrated nutrient management system can bring about equilibrium between degenerative and restorative activities in the soil eco-system (Upadhyay et al., 2011).

Green manuring has twin benefits of soil quality and fertility enhancement while meeting a part of nutrient needs of crop. Organic manures provide regulate supply of $\mathrm{N}$ by releasing it slowly resulting in increased yield of rice and nutrient use efficiency (Sharma 2002). Integrated use of inorganic fertilizers, organic manures, green manures and crop residue are the only alternatives which may help in improving soil health and sustained productivity. Use of organic manures, green manures, crop residues along with inorganic fertilizers not only reduces the demand of inorganic fertilizers but also increases the efficiency of applied nutrients due to their favorable effect on physical, chemical and biological properties of soil (Pandey et al., 2007), as organic manure provide a good substrates for the growth of microorganism and maintain a favorable nutrient supply to crop and achieve sustainable crop production.

In hilly and coastal zone of Karnataka, Eupatorium (Chromolaena odorata L.) is a problematic weed (Mogali, 1982) found in abundance all along roadside, on field bunds, wastelands and degraded forests (Doddamani, 1992). Its spread in to cultivated areas created a problem for plantation and food crops. Favorable effect of eupatorium green manure on growth and yield of rice has been reported by several workers (Thakur and Singh, 1987 and Angadi et al., 1997). Its use as green manure in rice before seed setting could be a possible way to check its spread in unwanted areas (Anwarulla, 1996). Among the green manures, Glyricidia sepium is fast growing and best known multipurpose trees in many parts of the world. It improves mobilization of native soil nutrients in the soil due to production of carbon dioxide and organic acids during decomposition of the plant material, adds valuable nutrients such as $\mathrm{N}, \mathrm{P}$, $\mathrm{K}, \mathrm{Ca}$ and $\mathrm{Mg}$ to the soil. Glyricidia plants grown on $700 \mathrm{~m}$ long bunds can provide about $30 \mathrm{~kg} \mathrm{~N}^{-1}$ year $^{-1}$ under rain fed systems (Wani et al., 2009). Application of green manures imparts resilience to soil against moisture stress, improves soil quality and reduces soil erosion and pollution besides helping to minimize use of chemical fertilizers. It reduces the nitrogen oxide $\left(\mathrm{N}_{2} \mathrm{O}\right)$ 
and $\mathrm{CO}_{2}$ emissions into atmosphere and contributes overall reduction in green house gases (GHGs) and has far reaching benefits in the climate change scenario (Wani et al., 2003).

\section{Materials and Methods}

A field experiment was conducted during kharif season of 2018 at Zonal Agricultural and Horticultural Research Station, Mudigere, Chikkamagaluru district, Karnataka, to study the integrated nutrient management in paddy. The experimental site is located at $13^{\circ} 7^{\prime}$ North latitude and $74^{\circ} 37^{\prime}$ East longitude with an altitude of $980 \mathrm{~m}$ above mean sea level. The soil of the experimental site was sandy loam in texture and $\mathrm{pH}$ was acidic (6.15), with normal salt load (EC $0.053 \mathrm{~d} \mathrm{Sm}^{-1}$ ). The organic carbon content was low $\left(4.7 \mathrm{~g} \mathrm{~kg}^{-1}\right)$. The soil was medium in available nitrogen (325.00 kg ha ${ }^{-1}$ ), high in available phosphorus (62.01 $\mathrm{kg} \mathrm{ha}^{-1}$ ) and medium in available potassium (102.27 $\mathrm{kg} \mathrm{ha}^{-1}$ ). KHP-13 a popular variety was transplanted in July with a spacing of $20 \mathrm{~cm} \times 10 \mathrm{~cm}$. The experiment was laid out in Randomized Complete Block Design consisting of ten treatments and replicated thrice. The treatment combination includes $\mathrm{T}_{1}-100 \% \mathrm{RDF}, \mathrm{T}_{2-} 100 \% \mathrm{RDF}+$ FYM, $\mathrm{T}_{3}-100 \%$ RDF + Glyricidia equivalent to FYM, $\mathrm{T}_{4}-100 \% \mathrm{RDF}+$ Eupatorium equivalent to FYM, $\mathrm{T}_{5^{-}} 100 \% \mathrm{RDF}+\mathrm{FYM}+$ PGPR, $\mathrm{T}_{6}-100 \% \mathrm{RDF}+$ Glyricidia + PGPR, $\mathrm{T}_{7}-100 \% \mathrm{RDF}+$ Eupatorium + PGPR, $\mathrm{T}_{8^{-}}$ $100 \% \mathrm{RDF}+\mathrm{PGPR}, \mathrm{T}_{9-} 100 \% \mathrm{RDF}+$ Glyricidia (50\%) + Eupatorium $(50 \%)+$ PGPR and $\mathrm{T}_{10^{-}} 100 \% \mathrm{RDF}+$ Glyricidia $(50 \%)+$ Eupatorium $(50 \%)$. The organic manures were incorporated in soil 25 days before transplanting of paddy. Yield (biological and economical) was recorded from individual plots at harvest and expressed in $\mathrm{kg} \mathrm{ha}^{-1}$ Standard statistical methods were used for comparing the treatment means.

\section{Results and Discussion}

\section{Uptake of nutrients by paddy}

The data on total uptake of nitrogen, phosphorus and potassium by paddy crop as influenced by integrated nutrient management are presented in Table 1.

\section{Total uptake of nitrogen $\left(\mathrm{kg} \mathrm{ha}^{-1}\right)$}

Results pertaining to the total uptake of nitrogen at harvest were found significant. Higher nitrogen uptake (110.81 kg ha $\left.{ }^{-1}\right)$ was observed in the 100 per cent RDF + glyricidia $(50 \%)+$ eupatorium $(50 \%)+$ PGPR $\left(\mathrm{T}_{9}\right)$ followed by $\mathrm{T}_{5}-100 \% \mathrm{RDF}+\mathrm{FYM}+\mathrm{PGPR}$ (108.21). Whereas lowest was recorded in $T_{1}$ -100 per cent RDF (79.04 $\left.\mathrm{kg} \mathrm{ha}^{-1}\right)$ treatment.

Higher nitrogen uptake with the application of inorganic fertilizer might be due to higher nitrogen concentration through addition of green manures along with higher biomass production. The results were in confirming with the findings of (Banik et al., 2006), Singh (2006), Pandey et al., (2007) and (Macedo, 2008).

\section{Total uptake of phosphorus (kg ha $\left.{ }^{-1}\right)$}

The trend of total phosphorus uptake followed similar pattern as that of nitrogen uptake. Significantly higher total phosphorus uptake (48.47 kg ha ${ }^{-1}$ ) was observed in 100 per cent $\mathrm{RDF}+$ glyricidia $(50 \%)+$ eupatorium $(50 \%)$ + PGPR $\left(\mathrm{T}_{9}\right)$ followed by $\mathrm{T}_{5}-100 \% \mathrm{RDF}+$ FYM + PGPR (46.27 kg ha $\left.{ }^{-1}\right)$. Whereas lowest was recorded in $T_{1}-100$ per cent RDF (29.99 $\left.\mathrm{kg} \mathrm{ha}^{-1}\right)$.

Green manuring for increasing efficiency of rock phosphate in soil, decomposition process, which is stimulated when green manure incorporated into the soil, can further increase the $\mathrm{P}$ availability by releasing $\mathrm{CO}_{2}$, 
which forms $\mathrm{H}_{2} \mathrm{CO}_{3}$ in the soil solution, resulting in the dissolution of primary $\mathrm{P}$ containing minerals. Also, organic acids released during decomposition may help dissolving soil mineral $\mathrm{P}$. The results were in line with findings of Tyagi (2003) and Kaushik (2004).

\section{Total uptake of potassium ( $\left.\mathrm{kg} \mathrm{ha}^{-1}\right)$}

Significantly higher total uptake of potassium $\left(62.80 \mathrm{~kg} \mathrm{ha}^{-1}\right)$ was recorded due to application of 100 per cent RDF+ eupatorium $+\operatorname{PGPR}\left(\mathrm{T}_{7}\right)$ followed by T9-100 per cent $\mathrm{RDF}+$ glyricidia $(50 \%)+$ eupatorium $(50 \%)$ + PGPR $\left(61.55 \mathrm{~kg} \mathrm{ha}{ }^{-1}\right.$. Whereas lowest uptake was recorded in T1-100 per cent RDF treatment $\left(41.87 \mathrm{~kg} \mathrm{ha}{ }^{-1}\right)$ and remaining treatments were on par with each other.

This might be due to eupatorium contains higher amount of $\mathrm{K}$, which is in the simple cationic $\mathrm{K}^{+}$form. Most soluble inorganic fertilizers and organic manures are virtually interchangeable as sources of $\mathrm{K}$ for plant nutrition (Li et al., 2006).

\section{Soil chemical properties after harvest of paddy}

Data on soil chemical properties viz., $\mathrm{pH}$, electrical conductivity and organic carbon after harvest of paddy as influenced by integrated nutrient management are presented in Table 2.

\section{Soil pH}

There was no significant difference in soil $\mathrm{pH}$ was noticed among all the treatments over the control. Numerically higher $\mathrm{pH}$ (5.85) was recorded in treatment which received 100 per cent $\mathrm{RDF}+$ glyricidia $(50 \%)+$ eupatorium $(50 \%)+$ PGPR $\left(\mathrm{T}_{9}\right)$ followed by $\mathrm{T}_{5}-100$ per cent RDF + FYM + PGPR (5.84) compared to other treatments and 100 per cent RDF with $\mathrm{pH}$ of 5.13.

\section{Electrical conductivity $\left(\mathrm{d} \mathrm{Sm}^{-1}\right)$}

No significant differences were found in electrical conductivity of soil due to integrated nutrient management. However, lowest $0.0454 \mathrm{~d} \mathrm{Sm}^{-1}$ in 100 per cent RDF+ glyricidia + PGPR, whereas highest in 100 per cent RDF + FYM + PGPR (0.1160 d $\mathrm{Sm}^{-1}$ ).

\section{Organic carbon $(\%)$}

Significantly higher organic carbon content $(1.17 \%)$ was recorded with $100 \% \mathrm{RDF}+$ eupatorium+ PGPR $\left(\mathrm{T}_{7}\right)$. The lowest organic carbon content $(1.00 \%)$ was recorded in 100 per cent recommended dose of fertilizers (T1).

Available nitrogen, phosphorus $\left(\mathrm{P}_{2} \mathrm{O}_{5}\right)$ and potassium $\left(\mathrm{K}_{2} \mathrm{O}\right)$

Data on available nitrogen, phosphorus $\left(\mathrm{P}_{2} \mathrm{O}_{5}\right)$ and potassium $\left(\mathrm{K}_{2} \mathrm{O}\right)$ differed significantly due to integrated nutrient management are presented in Table 2.

\section{Available nitrogen}

Available nitrogen in soil after harvest of paddy differed significantly due to different treatment combinations. Higher available nitrogen was recorded in T2 - 100 per cent RDF + FYM (371.14 $\mathrm{kg} \mathrm{ha}^{-1}$ ) followed by T8 -100 per cent RDF + PGPR (361.55 kg ha ${ }^{-1}$ ) and T7 -100 per cent RDF + eupatorium + PGPR (359.50 kg ha-1). Lower availability values of $345.68 \mathrm{~kg} \mathrm{ha}^{-1}$ were recorded in the treatment $\mathrm{T} 9$.

Slow release of nitrogen from FYM might have reduced the $\mathrm{N}$ loss from soil since organic carbon in the soil is higher than that from inorganic fertilizer application. Inorganic fertilizers cause immediate release of nutrients, which will be utilized by the crop or may be lost into the environment through 
leaching or denitrification process. Similar results were also noted by Tarfa et al., (2006) and Singh and Singh (2008).

\section{Available phosphorus $\left(\mathbf{P}_{2} \mathbf{O}_{5}\right)$}

The data revealed that significant influence of treatments on phosphorus availability and was higher in combined application of T6-100 per cent RDF + Glyricidia + PGPR (68.19 $\mathrm{kg} \mathrm{ha}{ }^{-1}$ ), followed by 100 per cent RDF + glyricidia and 100 per cent RDF + FYM + PGPR (67.49 and $66.70 \mathrm{~kg} \mathrm{ha}^{-1}$, respectively). Whereas lowest available nitrogen was recorded in 100 per cent RDF treatment $\left(58.12 \mathrm{~kg} \mathrm{ha}^{-1}\right)$.

High available soil phosphorus could be attributed to increased solubility of native $\mathrm{P}$ by means of organic acids produced during the course of decomposition. Prabhakar et al., (1972) found that application of Glyricidia green manure to soil @ $4.4 \mathrm{Mg} \mathrm{ha}^{-1}$ increased the available $\mathrm{P}$ content of the soil significantly over the 100 per cent RDF.

Among all the treatments, the plots receiving 100 per cent organic treatment showed highest amount of available $\mathrm{P}$ irrespective of the tillage practices adopted.

\section{Available potassium $\left(\mathrm{K}_{\mathbf{2}} \mathrm{O}\right.$ :}

Significantly higher availability of potassium in soil was obtained with application of 100 per cent RDF + eupatorium + PGPR (150.36 $\left.\mathrm{kg} \mathrm{ha}^{-1}\right)$, followed by T9 $\left(145.02 \mathrm{~kg} \mathrm{ha}^{-1}\right)$ and T4 (137.86 kg ha ${ }^{-1}$ ) however lower available potassium observed in T1-100 per cent RDF treatment $\left(115.58 \mathrm{~kg} \mathrm{ha}^{-1}\right)$.

This may be attributed to eupatorium accumulate about 40 to 50 per cent of total absorbed $\mathrm{K}$ and its recycling would substantially save inorganic fertilizer and help in soil K sustainability (Munir, 2014).
Major benefit obtained from eupatorium was the addition of organic matter to the soil and increased soil microorganisms. The addition of organic matter i.e. green manures indicated higher bulk density, nutrient content and water holding capacity. It means that there was higher production of mycorrhizal spores that bound soil particles and increased the compactness of soil with the increment in the soil nutrient contents (Kiran Kumar et al., 2002).

\section{Soil microbial biomass}

Data on population of soil microbes' viz., bacteria, fungi and actinomycetes after harvest of paddy as influenced by integrated nutrient management are presented in Table 2 and they differed due to various treatments. Soil microbial population was higher with supplemental addition of organics treatments than the recommended dose of fertilizers (RDF).

\section{Bacteria population (cfu $\times 10^{5} \mathrm{~g}^{-1}$ of soil)}

Combined application of 100 per cent RDF + glyricidia $(50 \%)+$ eupatorium $(50 \%)+$ PGPR treatment found significantly higher bacterial population $\left(31.78 \mathrm{cfu} \times 10^{5} \mathrm{~g}^{-1}\right.$ of soil) and it was followed by T10 and T5, $\left(29.50\right.$ and $28.85 \mathrm{cfu} \times 10^{5} \mathrm{~g}^{-1}$ of soil, respectively). Whereas lowest bacterial population were recorded in T1-100 per cent RDF treatment (20.01 cfu $\times 10^{5} \mathrm{~g}^{-1}$ of soil).

\section{Fungi population (cfu $\times 10^{3} \mathrm{~g}^{-1}$ of soil)}

Significantly higher population of fungi found in treatment T9 $\left(40.75 \mathrm{cfu} \times 10^{3} \mathrm{~g}^{-1}\right.$ of soil), followed by T5-100 per cent RDF + FYM + PGPR and T10-100 per cent RDF + glyricidia $(50 \%)+$ eupatorium (50\%) (39.82 and 37.47 cfu $\times 10^{3} \mathrm{~g}^{-1}$ of soil, respectively). Whereas lowest fungi population were recorded in T1100 per cent RDF treatment $\left(23.27 \mathrm{cfu} \times 10^{3}\right.$ $\mathrm{g}^{-1}$ of soil). 
Table.1 Uptake of nitrogen, phosphorus and potassium by paddy as influenced by integrated nutrient management

\begin{tabular}{|c|c|c|c|c|c|c|c|c|c|}
\hline \multirow[t]{2}{*}{ Treatments } & \multicolumn{3}{|c|}{ Nitrogen uptake $\left(\mathrm{kg} \mathrm{ha}^{-1}\right)$} & \multicolumn{3}{|c|}{ Phosphorus uptake $\left(\mathrm{kg} \mathrm{ha}^{-1}\right)$} & \multicolumn{3}{|c|}{ Potassium uptake $\left(\mathrm{kg} \mathrm{ha}^{-1}\right)$} \\
\hline & Grain & Straw & Total & Grain & Straw & Total & Grain & Straw & Total \\
\hline $\mathrm{T}_{1}-100 \% \mathrm{RDF}$ & 43.40 & 35.64 & 79.04 & 17.65 & 12.34 & 29.99 & 20.71 & 21.16 & 41.87 \\
\hline $\mathrm{T}_{2}-100 \% \mathrm{RDF}+\mathrm{FYM}$ & 48.82 & 41.14 & 89.96 & 19.64 & 15.26 & 34.90 & 24.42 & 25.89 & 50.31 \\
\hline $\mathrm{T}_{3^{-}} 100 \% \mathrm{RDF}+$ glyricidia equivalent to FYM & 53.15 & 45.50 & 98.65 & 23.63 & 16.59 & 40.22 & 28.62 & 29.94 & 58.56 \\
\hline $\begin{array}{l}\text { T }_{4-100} \% \text { RDF + eupatorium equivalent to } \\
\text { FYM }\end{array}$ & 54.36 & 48.47 & 102.83 & 24.42 & 17.61 & 42.03 & 29.26 & 31.27 & 60.53 \\
\hline $\mathrm{T}_{5}-100 \% \mathrm{RDF}+\mathrm{FYM}+\mathrm{PGPR}$ & 58.70 & 49.51 & 108.21 & 27.87 & 18.40 & 46.27 & 26.75 & 27.93 & 54.68 \\
\hline $\mathrm{T}_{6}-100 \% \mathrm{RDF}+$ glyricidia+ PGPR & 56.04 & 49.14 & 105.18 & 27.63 & 18.06 & 45.69 & 26.97 & 27.64 & 54.61 \\
\hline $\mathrm{T}_{7}-100 \%$ RDF + eupatorium+ PGPR & 51.28 & 44.72 & 96.00 & 21.90 & 16.23 & 38.13 & 30.59 & 32.21 & 62.80 \\
\hline $\mathrm{T}_{8^{-}} 100 \%$ RDF + PGPR & 47.71 & 39.16 & 86.87 & 18.12 & 14.36 & 32.48 & 24.08 & 25.07 & 49.15 \\
\hline $\begin{array}{l}\text { T}_{9-}-100 \% \text { RDF + glyricidia }(50 \%)+\text { eupatorium } \\
(50 \%)+\text { PGPR }\end{array}$ & 59.46 & 51.35 & 110.81 & 29.26 & 19.21 & 48.47 & 29.80 & 31.75 & 61.55 \\
\hline $\begin{array}{l}\mathrm{T}_{10}-100 \% \mathrm{RDF}+\text { glyricidia }(50 \%)+ \\
\text { eupatorium }(50 \%)\end{array}$ & 50.25 & 43.78 & 94.03 & 21.04 & 15.83 & 36.87 & 29.08 & 31.16 & 60.24 \\
\hline S. Em \pm & 3.34 & 2.76 & 5.70 & 2.26 & 1.17 & 3.19 & 3.16 & 3.19 & 6.18 \\
\hline $\mathrm{CD}(\mathrm{P}=\mathbf{0 . 0 5})$ & 9.95 & 8.20 & 16.95 & 6.72 & 3.48 & 9.47 & 9.43 & 9.50 & 18.34 \\
\hline
\end{tabular}

Note: RDF @ 75:75:90 kg N: $\mathrm{P}_{2} \mathrm{O}_{5}: \mathrm{K}_{2} \mathrm{O} \mathrm{ha}^{-1}$, FYM @ $10 \mathrm{tha}^{-1}$, Glyricidia @ $7.4 \mathrm{tha}^{-1}$,Eupatorium @ $8.10 \mathrm{tha}^{-1}$, DAT- Day after transplanting 
Table.2 Chemical properties, nutrient status of soil and soil microorganism after harvest of paddy as influenced by integrated nutrient management

\begin{tabular}{|c|c|c|c|c|c|c|c|c|c|}
\hline \multirow[t]{2}{*}{ Treatments } & \multicolumn{3}{|c|}{ Chemical properties } & \multicolumn{3}{|c|}{ Available nutrient } & \multicolumn{3}{|c|}{ Soil microorganism } \\
\hline & $\mathbf{p H}$ & $\begin{array}{c}\mathrm{EC} \\
\left(\mathrm{dSm}^{-1}\right)\end{array}$ & $\begin{array}{c}\text { Organic } \\
\text { carbon }(\%)\end{array}$ & $\mathbf{N}$ & $\mathbf{P}_{2} \mathrm{O}_{5}$ & $\mathbf{K}_{2} \mathbf{O}$ & $\begin{array}{c}\text { Bacteria } \\
\left(\text { cfu } x 10^{5} \mathrm{~g}^{-1} \text { of }\right. \\
\text { soil })\end{array}$ & $\begin{array}{l}\text { Fungi } \\
\left(\text { cfu } x 10^{3} \mathrm{~g}^{-1}\right. \\
\text { of soil })\end{array}$ & $\begin{array}{l}\text { Actinomycetes } \\
\left(\text { cfu } \times 10^{4} \mathrm{~g}^{-1} \text { of }\right. \\
\text { soil })\end{array}$ \\
\hline $\mathrm{T}_{1-} \mathbf{1 0 0} \% \mathrm{RDF}$ & 5.13 & 0.07 & 1.00 & 314.49 & 58.12 & 115.58 & 20.01 & 23.27 & 10.10 \\
\hline $\mathrm{T}_{2^{-}} \mathbf{1 0 0} \% \mathrm{RDF}+\mathrm{FYM}$ & 5.93 & 0.08 & 1.13 & 371.14 & 58.45 & 124.17 & 26.59 & 33.52 & 13.44 \\
\hline $\begin{array}{l}\mathrm{T}_{3-}-100 \% \mathrm{RDF}+\text { glyricidia } \\
\text { equivalent to } \mathrm{FYM}\end{array}$ & 5.39 & 0.05 & 1.04 & 349.13 & 67.49 & 125.26 & 22.94 & 32.70 & 11.60 \\
\hline $\begin{array}{l}\mathrm{T}_{4}-100 \% \mathrm{RDF}+\text { eupatorium } \\
\text { equivalent to } \mathrm{FYM}\end{array}$ & 5.46 & 0.06 & 1.08 & 358.21 & 63.42 & 137.86 & 24.55 & 36.30 & 12.48 \\
\hline $\mathrm{T}_{5^{-}} 100 \% \mathrm{RDF}+\mathrm{FYM}+\mathrm{PGPR}$ & 5.84 & 0.11 & 1.16 & 347.60 & 66.70 & 124.41 & 28.85 & 37.47 & 13.72 \\
\hline $\mathrm{T}_{6-1} 100 \%$ RDF + glyricidia+ PGPR & 5.27 & 0.04 & 1.07 & 354.76 & 68.19 & 125.97 & 27.54 & 36.58 & 12.29 \\
\hline $\begin{array}{l}\text { T }_{7-100} \% \text { RDF + eupatorium+ } \\
\text { PGPR }\end{array}$ & 5.68 & 0.05 & 1.17 & 359.50 & 61.22 & 150.36 & 28.72 & 37.29 & 12.81 \\
\hline$T_{8-100} \%$ RDF + PGPR & 5.22 & 0.07 & 1.03 & 361.55 & 55.87 & 123.07 & 21.62 & 31.50 & 11.56 \\
\hline $\begin{array}{l}\text { T}_{9-} 100 \% \text { RDF + glyricidia }(50 \%)+ \\
\text { eupatorium }(50 \%)+\text { PGPR }\end{array}$ & 5.85 & 0.05 & 1.10 & 345.68 & 58.65 & 145.02 & 31.78 & 40.75 & 15.11 \\
\hline $\begin{array}{l}\mathrm{T}_{10}-100 \% \mathrm{RDF}+\text { glyricidia }(50 \%) \\
\text { + eupatorium }(50 \%)\end{array}$ & 5.82 & 0.08 & 1.09 & 356.64 & 61.73 & 128.26 & 29.50 & 39.82 & 14.70 \\
\hline S. Em \pm & 0.29 & 0.032 & 0.04 & 14.91 & 2.69 & 5.61 & 2.88 & 4.58 & 0.92 \\
\hline $\mathrm{CD}(\mathrm{P}=0.05)$ & NS & NS & 0.12 & 44.36 & 7.98 & 16.65 & 8.55 & 14.00 & 2.73 \\
\hline
\end{tabular}

Note: RDF @ 75:75:90 kg N: $\mathrm{P}_{2} \mathrm{O}_{5}: \mathrm{K}_{2} \mathrm{O} \mathrm{ha}^{-1}$, FYM @ $10 \mathrm{t} \mathrm{ha}^{-1}$, Glyricidia @ $7.4 \mathrm{t} \mathrm{ha}^{-1}$,Eupatorium @ $8.10 \mathrm{t} \mathrm{ha}^{-1}$, DAT- Day after transplanting 
Table.3 Yield and yield attributes of paddy (Oryza sativa L.) as influenced by integrated nutrient management

\begin{tabular}{|c|c|c|c|c|c|c|c|}
\hline Treatments & $\begin{array}{l}\text { No. of } \\
\text { productive } \\
\text { tillers hill-1 }\end{array}$ & $\begin{array}{c}\text { Panicle } \\
\text { length }(\mathrm{cm})\end{array}$ & $\begin{array}{l}\text { Panicle } \\
\text { weight } \\
\left(\mathrm{g} \text { hill }^{-1}\right)\end{array}$ & $\begin{array}{l}\text { Total no. } \\
\text { of grains } \\
\text { panicle }^{-1}\end{array}$ & $\begin{array}{l}1000 \text { grain } \\
\text { weight }(\mathrm{g})\end{array}$ & $\begin{array}{c}\text { Grain } \\
\text { yield } \\
\left(\mathrm{kg} \mathrm{ha}^{-1}\right)\end{array}$ & $\begin{array}{c}\text { Straw } \\
\text { yield } \\
\left(\mathrm{kg} \mathrm{ha}^{-1}\right)\end{array}$ \\
\hline $\mathrm{T}_{1}-100 \% \mathrm{RDF}$ & 12.20 & 16.49 & 2.56 & 103 & 23.50 & 4952 & 6293 \\
\hline $\mathrm{T}_{2-1}-100 \% \mathrm{RDF}+\mathrm{FYM}$ & 13.32 & 17.98 & 3.03 & 102 & 24.76 & 5159 & 6451 \\
\hline $\begin{array}{l}\mathrm{T}_{3-100} \% \mathrm{RDF}+\text { glyricidia } \\
\text { equivalent to FYM }\end{array}$ & 14.95 & 19.16 & 3.39 & 103 & 25.29 & 5354 & 6870 \\
\hline $\begin{array}{l}\mathrm{T}_{4-}-100 \% \mathrm{RDF}+\text { eupatorium } \\
\text { equivalent to FYM }\end{array}$ & 16.02 & 20.37 & 3.58 & 108 & 24.99 & 5527 & 7094 \\
\hline $\mathrm{T}_{5}-100 \% \mathrm{RDF}+\mathrm{FYM}+\mathrm{PGPR}$ & 17.72 & 21.22 & 3.95 & 121 & 25.80 & 5652 & 7295 \\
\hline $\begin{array}{l}\text { T6- }_{6} 100 \% \text { RDF + glyricidia+ } \\
\text { PGPR }\end{array}$ & 16.40 & 20.58 & 3.81 & 118 & 25.15 & 5565 & 7144 \\
\hline $\begin{array}{l}\mathrm{T}_{7}-100 \% \mathrm{RDF}+\text { eupatorium+ } \\
\text { PGPR }\end{array}$ & 13.68 & 18.82 & 3.22 & 116 & 24.83 & 5289 & 6807 \\
\hline $\mathrm{T}_{8}-100 \% \mathrm{RDF}+\mathrm{PGPR}$ & 13.18 & 17.65 & 2.98 & 98 & 23.68 & 5130 & 6389 \\
\hline $\begin{array}{l}\text { T9- } 100 \% \text { RDF + glyricidia }(50 \%) \\
\text { + eupatorium }(50 \%)+\text { PGPR }\end{array}$ & 18.41 & 22.29 & 4.13 & 128 & 25.36 & 5843 & 7477 \\
\hline $\begin{array}{l}\mathrm{T}_{10^{-}} 100 \% \text { RDF + glyricidia }(50 \%) \\
\text { + eupatorium }(50 \%)\end{array}$ & 13.39 & 18.66 & 3.15 & 106 & 24.97 & 5197 & 6573 \\
\hline S. Em \pm & 1.19 & 1.02 & 0.26 & 4.24 & 0.92 & 203 & 284 \\
\hline $\mathrm{CD}(\mathrm{P}=\mathbf{0 . 0 5})$ & 3.55 & 3.03 & 0.78 & 13.00 & NS & 603 & 838 \\
\hline
\end{tabular}

Note: RDF @ 75:75:90 kg N: $\mathrm{P}_{2} \mathrm{O}_{5}: \mathrm{K}_{2} \mathrm{O} \mathrm{ha}^{-1}$, FYM @ $10 \mathrm{tha}^{-1}$, Glyricidia @ $7.4 \mathrm{tha}^{-1}$,Eupatorium @ 8.10 tha ${ }^{-1}$, DAT- Day after transplanting 
Actinomycetes population (cfu $\times 10^{4} \mathrm{~g}^{-1}$ of soil)

Among the different INM treatments, actinomycetes population was found significantly higher with the application of 100 per cent $\mathrm{RDF}+$ glyricidia $(50 \%)+$ eupatorium $(50 \%)\left(15.11 \mathrm{~g}^{-1}\right.$ of soil $)$ and it was followed by $\mathrm{T} 9-100$ per cent RDF + glyricidia $(50 \%)+$ eupatorium $(50 \%)+$ PGPR and T5 -100 per cent RDF+ FYM + PGPR (14.70 and $13.72 \mathrm{cfu} \times 10^{4} \mathrm{~g}^{-1}$ of soil, respectively). Whereas lowest in $\mathrm{T} 1$ (10.10 cfu $\times 10^{4} \mathrm{~g}^{-1}$ of soil).

Application of green manures and FYM was highly beneficial in improving bacteria, fungi and actinomycetes population in the soil. Similar results were reported by Mondal et al., (2003) and Kumaran, (2010) .

\section{Yield and yield attributes}

Influence of integrated nutrient management on yield and yield attributes at harvest is presented in Table 3. Among various treatments maximum number of productive tillers per hill (18.41), panicle length $(22.29 \mathrm{~cm})$, panicle weight $\left(4.13 \mathrm{~g}\right.$ hill $\left.^{-1}\right)$, total number of grains (128 panicle $\left.^{-1}\right), 1000$ grain weight $(25.36 \mathrm{~g})$, grain yield $\left(5843 \mathrm{~kg} \mathrm{ha}^{-1}\right)$ and straw yield $\left(7477 \mathrm{~kg} \mathrm{ha}^{-1}\right)$ was recorded by the application of 100 per cent recommended dose of fertilizers + Glyricidia (50\%) + eupatorium $(50 \%)+\operatorname{PGPR}\left(\mathrm{T}_{9}\right)$, followed by 100 per cent recommended dose of fertilizers $+\mathrm{FYM}+\operatorname{PGPR}\left(\mathrm{T}_{5}\right)$. Higher yield and yield attributing parameters may be due to better carbon assimilation and accumulation of carbohydrates in the plant.

Number of productive tillers increased with supplemental addition of $\mathrm{N}$ and $\mathrm{K}$ through green manures, which could be attributed to the influence of $\mathrm{N}$ on leaf development, tiller production and increasing leaf photosynthetic activity (Ntanson and Koutroubas, 2002). In RDF treatment, insufficient nutrients for filling of grains led to diminished grain number per panicle; thus, in this state, lower competition is the cause of decreased hallow grain percentage in panicle. The results were in accordance with the findings of Esfehani $e t$ al., (2005) and (Ramachandra Prasad et al., 2016).

Grain yield and straw yield of paddy was significantly influenced by the combined application of 100 per cent recommended dose of fertilizers, green manures and biofertilizers. Increase in 1000 grain weight, grain yield and straw with treatment $\mathrm{T}_{9}-\mathrm{RDF}$ + glyricidia $(50 \%)+$ eupatorium $(50 \%)+$ PGPR followed by $\mathrm{T}_{5}-100$ per cent RDF + FYM + PGPR.

This might be due to better nitrogen and chlorophyll content of plant at panicle emergence and grain filling period consequent to an increasing availability of nitrogen to rice crop maintained complimentary source-sink relationship. Thus the increase in growth and yield owing to the application of $\mathrm{N}$-fertilizers may be due to nitrogen is an important constituents of nucleotides, proteins, chlorophyll and many enzymes, involved in various metabolic processes which have direct impact on vegetative and reproductive phases of plants. With increment of nitrogen fertilizer, grain yield increased relatively, but further increase in nitrogen level produced higher straw yield. These findings are supported by Thomas and Thomas, (2009), Amit Kaul et al., (2015) and Glick, (2012).

\section{References}

Agriculture Statistical Year Book, (2017). From Government of India Ministry of Statistics and programme Implementation http://mospi.nic.in/Qstatistical-yearbook-India/2017/177. 
Anwarulla, M. S., 1996, Eupatorium weed-a green manure for rice. The Hindu Daily Dated, 2-5-1996.

Angadi, V. V., Chittapur, B. M., Basavaraj, B., Mohan Kumar, H. D., Hegde, Y. and Ganajaxi., 1997, Green manuring value of weeds in transplanted rice. First International Conference on Parthenium management. University of Agricultural Sciences, Dharwad, pp.126-127.

Amit, K., Kaul, R., Anil, K., Seema, C., and Dass, A., 2015, Importance of green manuring in sustainable agriculture. Popular Kheti, 3(2): 8-12.

Banik, P., Ghosal, P. K., Sasmal, T. K., Bhattacharya, S., Sarkar, B. K. and Bagchi, D. K., 2006, Effect of organic and inorganic nutrients for soil quality conservation and yield of rainfed low land rice in Sub-Tropical Plateau Region. J. Agron. Crop Sci., 192(5): 331-343.

Doddamani, M. B., 1992, Studies on the physiological and biochemical changes in Eupatorium odaratum (L.) as influenced by herbicides and allelopathic effects. Ph.D. Thesis, University of Agricultural Sciences, Dharwad.

Esfehani, M., Sadrzade, S. M., Kavoosi, M. and Dabagh-Mohammad-Nasab, A., 2005, Study the effect of different levels of nitrogen and potassium fertilizers on growth, grain yield, yield components of rice (Oryza sativa) cv. Khazar. Iran Agron. J., 7(3): 226-241.

Glick, B. R., 2012, Plant Growth-Promoting Bacterial-Mechanisms and Applications. Hindawi Publishing Corporation, Scientifica, Waterloo, Canada: 13-17.

Hugar, A.Y., Chandrappa, H., Jeyadeva, H.M., Satish, A. and Mallikarjun, G..B. 2009. Comparative performance of different rice establishment methods in bhadra command area. Karnataka J. Agric. Sci., 22: 992-994.

Kang, G. S., V. Beri, B. S. Sidhu, and O. P. Rupela. (2005). A new index to assess soil quality and sustainability of wheatbased cropping systems. Biology and Fertility of Soils.41: 389- 398.

Kaushik, B. D., 2004, Studies on different forms of phosphorus fertilizers in combination of biofertilizers in paddywheat cropping sequence. Ann. Agric. Res., 25: 179-186.

Kiran Kumar, V. K., Shivakumar and Muniyappa, T. V., 2002, Management of communist weed and its utilization as compost in finger millet. In: Conf. Extended Summaries-2 $2^{\text {nd }}$ Int. Agron. Congress, New Delhi, India, 1and 2:1196-1198.

Kumaran, 2010, Effect of nutrient sources on growth and yield of direct seeded rice (Oryza sativa L.) Crop Res., 29:19-23.

LI, X. F., Singh, B. And Rengel, Z., 2006, Decomposition of maize straw in saline soil. Biol. Fertil. Soils, 42: 366-370.

Macedo, M. O., Resende, A. S. Garcia. P. C., Boddey. R. M., Jantalia S. Urquiaga., Campello, E. F. C. and Franco, A. A., 2008, Changes in soil $\mathrm{C}$ and $\mathrm{N}$ stock and nutrient dynamics 13 years after recovery of degraded land using leguminous nitrogen-fixing trees: Forest Ecol.Manag., 255: 1516-1524.

Mogali, S. G., 1982, Studies on some aspects of seed biology autotoxicity, allelopathy and chemical control of Eupatorium odaratum. M.Sc. (Agri.) Thesis, Uni. of Agril. Sci. Bangalore.

Mondal, S. S., Sitamgshusarkar, Aruoghosh And Das. J., 2003, Response of summer rice (Oryza sativa L.) to different organic and inorganic sources of nutrients. Crop Res., 25(2):219-222.

Munir, J., 2014, Test of liquid organic fertilizer originated Chromolaena odorata and coconut fiber length with various compositions by fermentation. J. Env. Res. Develop., 9:1-6.

Ntanson, D. A. and Koutroubas, S. D., 2002, Dry matter and $\mathrm{N}$ accumulation and 
translocation for India and Japonica rice under Mediterranean conditions. Field Crop Res., 74: 93-101.

Pandey, N., Verma, A. K., Anurag and Tripathi, R.S. (2007).Integrated nutrient management in transplanted hybrid rice (Oryza sativa L.). Journal of Agronomy 52(1):40-42.

Prabhakar, A S., Patil, S V. and Krishnamurthy, K., 1972. Influence of organic manures, ammonical and nitrate nitrogen on the availability of soil and applied phosphorus. J. Indian Soc. Soil Sci., 20:413-415.

Ramachandra Prasad, T. V., Kumar Naik, A. H. and Basavaraja Naik, T., 2016, Influence of Chromolaena odorata compost on growth and yield of finger millet. J. Agric. Vet. Sci., 9(7): 20-24.

Ramesh, P., Panwar, N. R., Singh, A. B. and Ramanna, S. (2009). Production potential, nutrient uptake, soil fertility and economics of soybean (Glycine max)based cropping systems under organic, chemical and integrated nutrient management practices. Indian Journal of Agronomy. 54(3): 278-83.

Sharma, S. N. (2002). Nitrogen management in relation to wheat (Triticum aestivum) residue management in rice (Oryza sativa). Indian Journal of Agricultural Science, 72:449-452.

Singh, V., 2006, Productivity and economics of rice (Oryza sativa)-wheat (Triticum aestivum) cropping system under integrated nutrient-supply system in recently reclaimed sodic soil. Indian. J. Agron., 51(2): 81-84.

Singh, A. and Singh, N. P., 2008, Direct and residual effect organic and inorganic sources of nutrients under urdbean-rice cropping sequence in foot hills of Uttaranchal. Indian J. Agron., 51(2): 9799.

Tarfa, B. D., Kurch, I., Kamara, A. Y. and Magida, D. N., 2006, Influence of cereal- legume rotation on soil chemical properties, crop yield and striga control. J. Agron., 5(2): 362-368.

Thakur, K. S., and Singh, C M., 1987, Effect of organic wastes and $\mathrm{N}$ level on transplanted rice. Indian J. Agron., 32(2): 161-164.

Thomas, T. C. and Thomas, A. C., 2009, Vital role of potassium in the osmotic mechanism of stomata aperture modulation and its link with potassium deficiency. Plant Signal Behavour, 4(3):240-243.

Tyagi, M. K., 2003, Effect of rock phosphate and organic nutrients on growth, yield and uptake of nutrients in paddy. Indian J. Agric. Res., 37: 1-8.

Udhayakumar, K., and Ramasamy, S., 2016. Performance of rice varieties under sustainable organic nutrient management practices on dry matter production, grain and straw yield, harvest index of rice (Oryza sativa L.). Life Sciences Leaflets., 71: 48-55

Upadhyay, V. B., Jain. V., Vishwakarma, S. K. and Kumhar, A. K. (2011). Production potential, soil health, water productivity and economics of rice (Oryza sativa)based cropping systems under different nutrient sources. Indian Journal of Agronomy. 56(4): 311-16.

Wani. S. P., Pathak, P., Jangawad, L. S., Eswaran, H. and Singh, P. 2003, Improved management of vertisols in the semi-arid tropics for increased productivity and soil carbon sequestration. Soil use manag., 19-217222.

Wani, S. P., Sreedevi, T. K., Rockstrom, J. and Ramakrishna, Y. S., 2009. Rainfed agriculture- Past trend and future prospectus. Rainfed agriculture: Unlocking the potential. Comprehensive Assessment of Water Management in Agriculture Series. CAB International, Wallingford, UK, pp.1-35. 


\section{How to cite this article:}

Shreeshail, M. Hanumanthappa and Ganapathi, M. 2020. Influence of INM on Nutrient Uptake, Bio-chemical Properties of Soil and Yield Attributes of Paddy (Oryza sativa L.) under Hill Zone of Karnataka. Int.J.Curr.Microbiol.App.Sci. 9(05): 2818-2829.

doi: https://doi.org/10.20546/ijcmas.2020.905.324 